\title{
TITLE VI OF THE 1964 CIVIL RIGHTS ACT AND THE CLOSING OF A PUBLIC HOSPITAL
}

Title VI of the Civil Rights Act of $1964^{1}$ prohibits racial discrimination in programs or activities that receive federal funding. Courts have construed the statute to einpower both private parties ${ }^{2}$ and the federal government ${ }^{3}$ to take their grievances to court and challenge program officials to alter their policies or risk losing federal assistance. These courts, however, have not agreed upon the elements necessary for the plaintiff's prima facie slowing of a violation of Title VI. ${ }^{4}$

This note first establishes that the Supreme Court is moving toward the application of the intent standard used in adjudicating constitutional equal protection claims under Title VI. The note explores the problems that Title VI plaintiffs experience in proving discriminatory intent according to the Court's articulation of this burden of proof in recent equal protection cases. 5 Focusing on a series of unsuccessful challenges of urban-public-liospital closimgs, the note illustrates the injurious and racially disproportionate impact of government action when discriminatory intent is required to prove Title VI violations.

The injection of the intent standard into Title VI is unfortunate, because federal support will continue for local programs that have adverse consequences for a racial minority group. Application of the in-

1. 42 U.S.C. $\$ \S 2000 d$ to $d-4$ (1976). Title VI, in part, states that "[n]o person in the United States shall, on the ground of race, color, or national origin, be excluded froin participation in, be denied the benefits of, or be subjected to discrimination under any program or activity receiving Federal financial assistance." Id. §2000d.

2. See 1 C. Antieau, Federal Civil Rights Acts: Civil Practice $\$ 313$, at 525-27 (2d ed. 1980). See also Lau v. Nichols, 414 U.S. 563, 571 n.2 (1974) (Stewart, J., concurring).

3. See 1 C. ANTIEAU, supra note $2, \S 312$, at 525 .

4. See, e.g., NAACP v. Medical Center, Inc., 657 F.2d 1322, 1333-35 (3d Cir. 1981); Bryan v. Koch, 492 F. Supp. 212, 229 (S.D.N.Y.), affd, 627 F.2d 612 (2d Cir. 1980). A series of recent law journal articles have reviewed the controversy. See Abernathy, Title VI and the Constitution: $A$ Regulatory Model for Defining "Discrimination," 70 Geo. L.J. 1, 16-20 (1981); Note, The Prima Facie Case and Remedies in Title VI Hospital Relocation Cases, 65 CoRNell L. Rev. 689, 700-07 (1980); Note, Municipal Hospital Closings Under Title VI: A Requirement of Reasonable Justifications, 9 FORDHAM URB. L. J. 943, 956-66 (1981); Note, Maintaining Health Care in the Inner City: Title VI and Hospital Relocations, 55 N.Y.U.L. Rev. 271, 278-90 (1980); Note, Title VI: The Impact/Intent Debate Enters the Municipal Services Arena, 55 ST. JoHN's L. REv. 124, 130-35 (1980); Note, NAACP v. Medical Center, Inc.: The Evidentiary Hearing Under Title VI, 24 St. LouIS U.L.J. 579 (1980). See also Chavkin, Health Access and the Civil Rights Laws: The Smoking Gun and Other Sorrows, 15 Clearinghouse Rev. 561 (1981).

5. See, e.g., Personnel Adm'r v. Feeney, 442 U.S. 256 (1979); Village of Arlington Heights v. Metropohtan Hous. Dev. Corp., 429 U.S. 252 (1977); Washington v. Davis, 426 U.S. 229 (1976). 
tent test will deprive minority communities of one important legal means to force local officials to implement alternative programs with less imjurious consequences. As the hospital closing cases show, the imtent standard does not protect citizens from discriminatory effects, even when those effects are as serious as the lack of medical services resulting from the closing of a municipal hospital.

\section{Title VI and the Requirement of Discriminatory INTENT}

Federal courts have not yet produced a definitive standard to identify racial discrimination forbidden by Title VI. Awaiting a conclusive interpretation of Title VI by the Supreme Court, lower federal courts have apphed two separate tests, both derived from equal protection jurisprudence. The first test requires the plaimtiff to present evidence of a disproportionate and injurious impact of the defendant's action on the members of a racial mimority group. 6 The second test requires the plaimtiff to present evidence of the defendant's discriminatory intent in addition to showing the disproportionate impact of the defendant's action. ${ }^{7}$ The test chosen by a court significantly affects the outcome of the case because a plaintiff may be able to prove only impact and not intent. ${ }^{8}$

6. The impact test requires the plaintiff to prove that the defendant's facially neutral decision or action has injured disproportionately the members of the protected group relative to the injury to nonmembers. Plaintiffs are not required to demonstrate discriminatory intent. For example, in Gomillion v. Lightfoot, 364 U.S. 339 (1960), the Court struck down an Alabama statute that realigned the boundaries of the City of Tuskegee and had the "essential inevitable effect of [depriving] . . . the Negro petitioners discriminatorily of the benefits of residence in Tuskegee, including . . . the right to vote in municipal elections." Id. at 341. Because of its discriminatory effect, the statute was held to be in violation of the fifteenth annendinent rights of the black voters. See, e.g. , Griggs v. Duke Power Co., 401 U.S. 424, 432 (1971) (impact test used to identify discriminatory employment practices under Title VII of the Civil Rights Act of 1964). See generally Perry, The Disproportionate Impact Theory of Racial Discrimination, 125 U. PA. L. REV. 540, 54448 (1977).

7. The intent test requires the plaintiff to present evidence-direct or circumstantial-establishing that the defendant acted with a specific discriminatory purpose. The imtent test has been used to determine whether a facially neutral decision or action that has a disproportionate impact on the members of a protected class violates the equal protection clause of the fourteenth amendment. Evidence of impact, by itself, is insufficient to establish an illegitimate purpose. See Village of Arlington Heights v. Metropohtan Hous. Dev. Corp., 429 U.S. 252 (1977); Washington v. Davis, 426 U.S. 229 (1976). See generally Note, Discriminatory Purpose and Disproportionate Impact: An Assessment After Feeney, 79 Colum. L. REv. 1376, 1378-85 (1979).

8. The choice between these threshold tests has become increasingly important as the nature of Title VI cases (and equal protection cases) has changed. Most practices challenged today are racially neutral on their face. See Regents of the Univ. of Cal. v. Bakke, 438 U.S. 265, 349 n. 17 (1978) (Brennan, White, Marshall, and Blackmun, JJ., concurring in part, dissenting in part); Belton, Burdens of Pleading and Proof in Discrimination Cases. Toward a Theory of Procedural Juslice, 34 V AND. L. REv. 1205, 1224, 1281-82 (1981) ("[T]t is increasingly rare to encounter the kinds of direct and overt practices that originally prompted Congress to enact the discrimimation laws. 
In Regents of the University of California v. Bakke, ${ }^{9}$ the Supreme Court took the first step toward determining the burden of proof under Title VI. In Bakke the plaimtiff challenged a special admissions policy for minority students at the medical school of the University of Califorma at Davis. The plaintiff alleged that his exclusion from the federally assisted medical school violated Title VI because express racial quotas were included in the admissions policy. ${ }^{10}$ Five Justices, im dicta in two separate opinions, observed that the test for Title VI discrimination should not be broader than the test used for an equal protection violation under the fifth and fourteenth amendments. ${ }^{11}$

The Justices based their conclusion on a review of the congressional debates concerning the enactment of the Act. ${ }^{12}$ In those debates, proponents of the Act argued that Title VI was necessary to terminate federal support of state and local programs that were racially segregated on a separate-but-equal basis. ${ }^{13}$ The Justices concluded that Congress viewed Title VI as part of an effort to implement the inandate of Brown v. Board of Education, ${ }^{14}$ in which the Court held that a separate-but-equal arrangement for public schools violated the equal protection clause of the fourteenth amendment. ${ }^{15}$ Furthermore, Congress intended Title VI to remove all federal support from state and local programs that violated the Brown Court's interpretation of equal pro-

Many claims of discrimination today deal with systemic, subtle, and sterotypical [sic] practiceswhich developed when overt discrimination was lawful - and are imbedded in basic institutional and organizational structures." Id. at 1224.); Schwemm, From Washington to Arlington Heights and Beyond: Discriminatory Purpose in Equal Protection Litigation, 1977 U. ILL. L.F. 961, 974.

9. 438 U.S. 265 (1978).

10. Id. at 272-81 (Powell, J., announcing the judgment of the Court). See generally Bakke v. Regents of the Univ. of Cal., 18 Cal. 2d 34, 553 P.2d 1152, 132 Cal. Rptr. 680 (1976), affd in part and rev'd in part, 438 U.S. 265 (1978).

11. 438 U.S. at 287 (dicta) (Powell, J.); id. at 328-40 (dicta) (Brennan, White, Marshall, and Blackmun, J.J., concurring in part, dissenting in part). Justice Stevens's opinion does not address the question of the appropriate test for Title v1. See also NAACP v. Medical Center, Inc., 657 F.2d 1322 (3d Cir. 1981). In Medical Center the Court of Appeals for the Third Circuit narrowly interpreted the portions of the Bakke opmions that address Title VI and held that Title VI requires only a showing of discriminatory effect to establish a prima facie case. The Medical Center court distinguished Bakke, inaintaining that the constitutional intent standard applies only to those Title Vl plaintiffs who allege intentional discrimination in an affirmative action plan. Id. at 1329-30.

12. 438 U.S. at 284-87 (Powell, J.); id. at 328-40 (Bremian, White, Marshall, and Blackmun, $\mathrm{JJ}$., concurring in part, dissenting in part). But see Abernathy, supra note 4, at 20-32, 38-39 (arguing for an interpretation of the legislative intent of Title VI different from that reached by the Justices in Bakke).

13. See, e.g., 110 Cong. Rec. 1527-28 (1964) (remarks of Rep. Celler); id. at 1619-20 (remarks of Rep. Abernathy); id. at 5608-12 (remarks of Sen. Ervin); id. at 6046-53 (remarks of Sen. Johnston); $i d$. at 6544-47 (remarks of Sen. Humphrey); id. at 6561-62 (remarks of Sen. Kuchel).

14. 347 U.S. 483 (1954).

15. Id. at 495. 
tection. ${ }^{16}$ Because the proponents of Title VI in Congress expected the Court's interpretation of constitutionally forbidden discrimination to control the enforcement of Title VI, they did not provide a standard or definition of discrimination to govern that Title. ${ }^{17}$ The five Justices in Bakke concurred that the Court should follow Congress's apparent intent to link Title VI to the Court's interpretation of equal protection. ${ }^{18}$

Even though two of the separate opinions in Bakke conclude that Congress intended the constitutional equal protection standard to govern the enforceinent of Title VI, neither opinion connects this conclusion to the Court's earker decision in Washington v. Davis. ${ }^{19}$ In Washington the Court held that a plaintiff must establish at least a prima facie case of the defendant's discriminatory intent to prove a constitutional violation of equal protection. ${ }^{20}$ In Bakke the Justices reviewed the legislative history to determine whether Title VI invalidates a state-sponsored affirmative-action plan and thus never expressly indicated what proof Title VI requires in a case of alleged injurious discrimination agamst minorities. ${ }^{21}$

In its 1979 decision in Board of Education v. Harris, 22 the Court again commented on, but did not decide, the appropriate test for Title

16. 438 U.S. at 286-87 (dicta) (Powell, J.); id. at 328-40 (dicta) (Brennan, White, Marshall, and Blackmun, J.J., concurring in part, dissenting in part). See 110 CoNG. REC. $6543-47$ (1964) (remarks of Sen. Humphrey); id. at 7062-64 (remarks of Sen. Pastore); id. at 13,333 (remarks of Sen. Ribicoff).

17. The opponents of Title VI strongly criticized the failure of the statute to independently define "discrimination." Senator Ervin complained that the silence of Title VI left the determination of a definition "to the executive department or agencies adininistering each program, without any guideline whatever to point out what is the congressional intent." 110 CoNG. REC. 5612 (1964) (remarks of Sen. Ervin). The preponents of Title VI rephed that the statute would follow the constitutional definition of discrimination. Representative Celler added, "Congress clearly has the power to legislate so as to insure that the Federal Government does not become involved in a violation of the Constitution." Id. at 1528 (remarks of Rep. Celler). See id. at 6561 (remarks of Sen. Kuchel); id. at 7057 (remarks of Sen. Pastore). Proponents apparently anticipated that the constitutional definition of discrimination would be further refined by the federal courts and that Title VI would follow this development. A separate definition of discrimination for Title VI was thought to create the risk that Title VI would allow federal support for programs which are valid nnder the statutory definition but which contain segregated arrangements otherwise held to be unconstitutional. See id. at 12,677 (remarks of Sen. Allot).

18. 438 U.S. at 286-87 (dicta) (Powell, J.); id. at 328 (dicta) (Brennan, White, Marshall, and Blackmun, J.J., concurring in part, dissenting in part).

19. 426 U.S. 229 (1976).

20. Id. at 242.

21. But see Regents of the Univ. of Cal. v. Bakke, 438 U.S. at 352 (dicta) (Brennan, White, Marshall, and Blackmun, JJ., concurring in part, dissenting in part) (by questioning the earher Title VI decision of Lau v. Nichols, 414 U.S. 563 (1974), Justice Brennan comes closest to adopting an intent requirement for Title VD. For a discussion of $\mathrm{Lau}$, see text accompanying notes 40 48 infra.

22. 444 U.S. 130 (1979). 
VI. ${ }^{23}$ The Court of Appeals for the Second Circuit had determined, based on its reading of congressional intent, that an impact test was appropriate for defining discrimination under both the Emergency School Aid Act (ESAA) ${ }^{24}$ and Title VI. ${ }^{25}$ The Supreme Court agreed that Congress had clearly imtended that an impact test govern the apphcation of the ESAA ${ }^{26}$ and affirmed the appellate court's decision solely on that basis. ${ }^{27}$ In so domg the Court avoided deciding the Title VI claim. ${ }^{28}$ In dicta, the majority distinguished Title VI from the ESAA ${ }^{29}$ and expressed a willingness to impose a narrower standard to identify Title VI discrimination. ${ }^{30}$ The majority commented that, in contrast to relief under the ESAA, Title VI relief-the termination of all federal funding-is so drastic that Congress reasonably could have desired the Title VI remedy to apply only im cases of intentional discrimination. ${ }^{31}$ The dissenting Justices im Harris also commented on Title VI and endorsed the reasoning found in Bakke that links Title VI to the constitutional test for discrimination. ${ }^{32}$ Considering Bakke and Harris, six Justices of the present Court have agreed to apply an intent standard to Title VI. ${ }^{33}$

The legislative history of Title VI provides additional support, not cited in Bakke or Harris, for requiring a showing of intent. During the 1964 congressional debates over Title VI, the statute's proponents rehed on Simkins v. Moses H. Cone Memorial Hospital, ${ }^{34}$ a decision handed down by the Court of Appeals for the Fourth Circuit. The Simkins court held that certam provisions of the Hill-Burton Act, ${ }^{35}$ which authorized federal support for hospitals that were racially segregated on a separate-but-equal basis, violated the equal protection

23. Id. at 149 (dicta).

24. 20 U.S.C. \& 3191 (Supp. III 1979).

25. Board of Educ. v. Califano, 584 F.2d 576, 588-89 (2d Cir. 1978), affd sub nom. Board of Educ. v. Harris, 444 U.S. 130 (1979).

26. 444 U.S. at $146-47$.

27. Id. at 149, 151-52.

28. Id. at 149 (dicta) ("There thus is no need here for the Court to be concerned with the issue whether Title VI . . . incorporates the constitutional standard . . . Consideration of that issue would be necessary only if there were a positive indication either in Title VI or in ESAA that the two Acts were intended to be coextensive").

29. "A violation of Title VI may result in a cutoff of all federal funds . . . In contrast, only ESAA funds are rendered unavailable when an ESAA violation is found." Id. at 150 .

30. Id. (dicta).

31. Id. (dicta).

32. Id. at 160 (Stewart, J., dissenting).

33. Justices Brennan, White, Marshall, Blackmun, and Powell stated their views in Bakke. See text accompanying note 11 supra. Justice Rehnquist joined Justice Stewart's dissent in Harris.

34. 323 F.2d 959 (4th Cir. 1963) (en banc), cert. denied, 376 U.S. 938 (1964).

35. Ch. 958, § 622(f), 60 Stat. 1041 (1946) (repealed 1964). 
clause. ${ }^{36}$ The supporters of Title VI used Simkins to illustrate judicial support for their contention that federal funding of any program that provides separate or unequal services to blacks is unconstitutional. ${ }^{37}$ Segregation in public programs was often expressly authorized by state law and, if not, separate-but-equal arrangements could have been explained only by the conscious discriminatory intent of official decisionmakers. The reliance on Simkins and on the examples of segregated programs provided by proponents of the Act ${ }^{38}$ strongly suggests that Congress intended Title VI to end federal support for separate-butequal racial segregation and other forms of unequal treatment intentionally imposed by state and local governments. Congress seeins to have considered discriminatory effects which occur in the absence of official intent to be beyond the reach of the statute. ${ }^{39}$

36. 323 F.2d at 970 .

37. See 110 Cong. Rec. 6561 (1964) (remarks of Sen. Kuchel); id. at 6544 (remarks of Sen. Humphrey). Federal legislation that allowed federal funds to be granted to separate-but-equal facilities included the Second Morrill Act of 1890, ch. 841, 26 Stat. 417 (current version at 7 U.S.C. $\S 323$ (1976)) (land-grant colleges) and the School Facilities Construction Act, ch. 995, \$\$ 201-202, 64 Stat. 969 (1950) (current version at 20 U.S.C. $\$ 636(b)(1)(F)$ (1976)) (provision that compliance with state law was adequate to ensure no discrimination implicitly allowed for separate-but-equal school construction that was valid under state law). See 110 CoNG. REC. 10,075-77 (1964) (letter from Att'y Gen. Keimedy to Sen. Cooper). See also United States Comm'N on Civil Rights, The Federal Civil Rights Enforcement EfFort-1974 3-4 (1975); Comment, Tille VI of the Civil Rights Act of 1964-Implementation and Impact, 36 GeO. WASH. L. REv. 824, 828-29 (1968).

38. Examples of programs which would come under Title VI included public schools, higher education, agricultural extension services, vocational training, and school lunches. See 109 CoNG. ReC. 23,531 (1963) (remarks of Sen. Javits); 110 CoNG. Rec. 6543-45 (1964) (remarks of Sen. Humphrey); id. at 7054-58 (remarks of Sen. Pastore); id. at 7100-03 (remarks of Sen. Javits).

39. Judge Wisdom, in the early Title VI case of United States v. Jefferson County Bd. of Educ., 372 F.2d 836 (5th Cir. 1966), affd en banc, 380 F.2d 385 (5th Cir.), cert. denied, 389 U.S. 840 (1967), observed that when Congress enacted Title VI, it was aware of an unsuccessful civil rights challenge to a de facto-segregated school system in Gary, Indiana and thus it did not intend Title VI to extend to federal funding involving programs characterized by de facto segregation. Id. at 881-82. The decision in the Gary, Indiana action referred to by Judge Wisdom, Bell v. School City, 213 F. Supp. 819 (N.D. Ind.), affd, 324 F.2d 209 (7th Cir. 1963), cert. denied, 377 U.S. 924 (1964), centered on the failure of the plaintiffs to show deliberate segregation; Brown v. Board of Education, 347 U.S. 483 (1954), did not apply because the plamtiff did not prove the existence of any state action. Additionally, some congressional supporters of Title VI suggested that im communities where segregation was not compelled by law, desegregation planning would be left to the state and local governments, not forced by an application of Title VI. See 110 CoNG. REC. 10,920 (1964) (remarks of Sen. Javits); id. at 5807, 5266 (remarks of Sen. Keating); id. at 13,821 (remarks of Sens. Humphrey and Saltonstall). But see Civil Rights-The President's Pro. gram, 1963: Hearings on S. 1731 and S. 1750 Before the Sen. Comm. on Judiciary, 88th Cong., 1st Sess. 255 (1963) (remarks by Att'y Gen. Kennedy suggesting that Title VI is directed at de facto school segregation in the North).

Senator Humphrey defined discrimination under Title II and Title VII of H.R. 7152, as amended (enacted as Title II and Title VII of the Civil Rights Act of 1964, \$\$ 201-207, 78 Stat. 243 (1964), and $\S \S 701-716,78$ Stat. 253 (1964), respectively), as requiring "a showing that those engaged in the pattern or practice [of discrimination] had the intention to deprive others of their rights . . ." 110 Cong. Rec. 14,270 (1964) (remarks of Sen. Humphrey). Senator Humphrey 
Despite the dicta in Bakke and Harris and the legislative history of Title VI, the question of the appropriate test for Title VI discrimination remaims unresolved. The imtent requirement test appears to be in direct conflict with the Court's 1974 decision in Lau v. Nichols. ${ }^{40}$ In Lau the Court followed the language of Title VI's implementing regulations and required only a showing of discriminatory effects to estabhish a violation of Title VI. ${ }^{41}$ The Courts of Appeals for the Third and the Ninth Circuits have continued to follow the Lau interpretation of Title VI; the Courts of Appeals for the Second, Fifth and Tenth Circuits, however, have expressed support for the intent standard. 42

In Lau the Court held that the San Francisco school system's failure to teach Enghish to Chinese-American students who did not speak Enghish was a violation of Title VI.43 The students did not allege that this failure was intentional, but claimed only that the effect of the schools' action was to deny the students equal access to educational benefits. ${ }^{44}$ Without the ability to communicate in Enghish, the students were "effectively foreclosed from any meaningful education." 45 The Court based its interpretation of Title VI on the language of the enforcement regulations issued by the Department of Health, Education,

provided this definition to defend Titles II and VII against the objection that they allowed the Attorney General "unlimited power to bring suit," $i d$., a charge that was also made against Title VI. While Senator Humphrey was answering only for Titles II and VII of the Act, it is not unreasonable to conclude that his fornulation also applied to Title VI.

40. 414 U.S. 563 (1974).

41. Id. at 567-69. The Lau decision precedes Washington v. Davis, 426 U.S. 229 (1976), and it does not focus on the Court's later emphatic distinction between the imtent and impact standards.

42. The cases supporting the continued use of the Lau standard include: NAACP v. Medical Center, Inc., 657 F.2d 1322, 1328-30 (3d Cir. 1981); Guadaloupe Org., Inc. v. Teinpe Elementary School Dist. No. 3, 587 F.2d 1022, 1029 \& n.6 (9th Cir. 1978); De La Cruz v. Tormey, 582 F.2d 45, 61 \& n.16 (9th Cir. 1978), cert. denied, 441 U.S. 965 (1979); Larry P. v. Riles, 495 F. Supp. 926, 964-65 (N.D. Cal. 1979). Cases supporting the application of the intent test imclude: Castaneda v. Pickard, 648 F.2d 989, 1000 (5th Cir. 1981); Guardians Ass'n v. Civil Service Comm'n, 633 F.2d 232, 257 (2d Cir. 1980), cert. granted, 50 U.S.L.W. 3547 (U.S. Jan. 11, 1982) (No. 81-431); Bryan v. Koch, 627 F.2d 612, 616 (2d Cir. 1980); Otero v. Mesa County Valley School Dist., 628 F.2d 1271, 1272 (10th Cir. 1980); Parent Ass'n of Andrew Jackson High School v. Ambach, 598 F.2d 705, 716 (2d Cir. 1979); United States v. Bexar County, 484 F. Supp. 855, 859 (W.D. Tex. 1980); Valadez v. Graham, 474 F. Supp. I49, 159 (M.D. Fla. 1979). See Note, Title VI: The Impaet/Intent Debate Enters the Municipal Services Arena, 55 ST. JoHN's L. Rev. 124, 131-32 (1980). See also Cannon v. University of Chicago, 648 F.2d 1104, 1109 (7th Cir.), cert. denied, 50 U.S.L.W. 3487 (U.S. Dec. 14, 1981) (No. 81-769) (dicta concluding that Title VI requires a showing of intentional discrimination).

43. 414 U.S. at $568-69$.

44. 414 U.S. at 564-69.

45. Id. at 566 . 
and Welfare (HEW). ${ }^{46}$ The regulations state that reeipients of federal funds "may not, directly or through contractual or other arrangements, utilize criteria or methods of administration which have the effect of subjectimg individuals to discrimination because of their race, color, or national origin . . ."47 The Court based its holding that the school system's language education policy violated Title VI solely on the students' demonstration of discriminatory impact. 48

The Court will have to overrule or distinguish Lau if an intent test is to be imposed for Title VI. ${ }^{49}$ When given the opportunity the Court will probably require a showing of discriminatory intent under Title VI, following its own reading of the legislative history of Title VI and not the language of the subsequent enforcement regulations cited in Lau. $^{50}$ If Title VI incorporates the constitutional definition of discrimination, then the Court's application of the intent test in recent equal protection cases will guide the courts in evaluating the inerit of Title VI claims.

46. Id. at 566-67. HEW was authorized to issue the regulations necessary to implement Title VI. See 42 U.S.C. \$2000d-I (1976). The Departments of Education and Health and Human Services are now responsible for these regulations. See 20 U.S.C. $\$ 3474$ (Supp. III 1979). The 1980 regulations remain identical to those considered in Lau. See note 47 infra.

47. 45 C.F.R. $\$ 80.3($ b)(2) (1980). See also 45 C.F.R. $\$ 80.3(b)(1)$ (1980) (general statement of the regulatory enforcement policy of Title VI).

48. 414 U.S. at 568.

49. Justice Brennan's opinion in Bakke expresses serious doubt about the correctness of the Court's previous use of the disproportionate-impact standard in Lau to identify discrimmation under Title VI. 438 U.S. at 352. The Bakke opinion cited Lau to demonstrate that programs that receive federal fnnds still have significant discretion to adopt race-conscious policies wliose specific purpose is to remedy the effects of past discrimination. Id. at 350-53 (dicta) (Brennan, White, Marshall, and Blackmun, JJ., concurring in part, dissenting in part).

In Fullilove v. Klutznick, 448 U.S. 448 (1980), the Court again cited Lau in a decision addressing affirmative action remedies. In Fullilove the Court uplield the constitutionality of a $10 \%$ allotment of federal coustruction funds for minority contractors. Id. at 491-92 (Burger, C.J., announcing the opinion of the Court). The Court cited Lau as a precedent supporting Congress's power to disburse federal funds contingent on the grantee's acceptance of federal rcgulation. Id. at 479-80. The Lau decision is discussed further because of the similarity between the "affirmative steps" required of the San Francisco school system in Lau and the 10\% allotment required of government contractors receiving funds under the minority busmess regulations. Id. at 479-80. The Fullilove Court empliasized the remedial aspect of the Lau decision, but did not address the use of the disproportionate impact test for Title VI.

50. Several Justices have already questioned the validity of the Lau imterpretation of Title VI. Regents of the Univ. of Cal. v. Bakke, 438 U.S. 265, 352 (1978) (dicta) (Brennan, White, Marshall, and Blackmun, J.J., concurring in part, dissenting in part). The interpretation of Title VI is presently before the Court in Guardians Ass'n v. Civil Serv. Comm'n, 633 F.2d 232 (2d Cir. 1980), cert. granted, 50 U.S.L.W. 3547 (U.S. Jan. 11, 1982) (No. 81-431). But see Abernathy, supra note 4. Professor Abernathy argues that Congress intended Title VI to be enforced according to the regulatory interpretation of administrative agencies. 


\section{Applying the Intent Test}

Recent equal protection cases clearly establish that evidence of racially disproportionate impact is insufficient to challenge statutes or government actions that are racially neutral on their face and that the plaintiff has the burden of presenting a prima facie case of discriminatory intent. ${ }^{51}$ Establishing a prima facie case of discriminatory intent is crucial for the equal protection plaintiff; such proof triggers the application of a strict standard of review. Once a prima facie case is established, the burden is shifted to the defendant, 52 who has the opportunity either to show a coinpelling state interest to justify the action $^{53}$ or to rebut the factual allegation of discriminatory intent. ${ }^{54}$

\section{A. The Development of the Equal Protection Intent Test.}

The Court's 1976 decision in Washington v. Davis ${ }^{55}$ marked the beginning of the developinent of the Court's express use of "intent" and "effects" to identify forbidden racial discrimination. Although the Washington Court did not completely dismiss evidence of the inipact of government action, it held that evidence of discriminatory intent is necessary to establish a prima facie case of discrimmation. ${ }^{56}$ The Court recognized that intent is not always expressed or plainly apparent and that circuinstantial evidence- "the totalilty of relevant facts"-including evidence of disproportionate impact may be used to infer intent. ${ }^{57}$ Nevertheless, the Washington Court emphasized that evidence of disproportionate impact alone does not suffice to prove intent. ${ }^{58}$

In the term following Washington, the Court began the process of deciding the acceptable sources of the proof of discriminatory intent. In Village of Arlington Heights v. Metropolitan Housing Development

51. Washington v. Davis, 426 U.S. 229, 242 (1976). Statutes using explicit racial categories are more easily challenged; the use of race is presumed invalid and the burden shifts to the defendant to sliow a compelling state justification. See Perry, The Disproportionate Impact Theory of Racial Discrimination, 125 U. PA. L. REv. 540, 550-51 (1977). Laws with racially neutral provisions pose inore significant problems today because they are more prevalent than racially explicit laws. Belton, supra note 8, at 1224; Schwemm, supra note 8, at 1002. See generally Note, Proving Discriminatory Intent From a Facially Neutral Decision With a Disproportionate Impact, 36 WASH. \& LEE L. REv. 109 (1979).

52. Alexander v. Louisiana, 405 U.S. $625,631-32$ (1972).

53. See Washington v. Davis, 426 U.S. 229, 242 (1976); McLaughlin v. Florida, 379 U.S. 184, 196 (1964).

54. Village of Arlington Heights v. Metropolitan Hous. Dev. Corp., 429 U.S. 252, 270 n.21

(1977); Washington v. Davis, 426 U.S. 229, 241 (1976). See also Belton, supra note 8, at 1249-50.

55. 426 U.S. 229 (1976).

56. Id. at 242 .

57. Id. at 241-42.

58. Id. at 242. 
Corp. ${ }^{59}$ Justice Powell listed four potential sources of evidence from which intent may be inferred: the historical background of the decision, the specific sequence of events leading up to the cliallenged decision, departures froin the normal procedural sequences, and the legislative or administrative history of the action. ${ }^{60}$

Since the Arlington Heights decision, however, the range of acceptable sources of evidence of intent has been significantly constricted. Based on dicta in Washington, ${ }^{61}$ several lower federal courts liad applied a reasonable foreseeability test-liolding that discriminatory intent may be inferred when the racially disproportionate and adverse impact of the defendant's action is reasonably foreseeable. ${ }^{62}$ The Court specifically disapproved of this standard in Personnel Administrator $\nu$. Feeney, ${ }^{63}$ explaining that although the inevitability or the foreseeability of disproportionate impact may add to the aggregate of evidence from whicl intent may be inferred, that evidence standing alone is msufficient to prove intent. ${ }^{64}$

In dicta, the Arlington Heights Court also described a potential affirmative defense to rebut a plaintiff's prima facie slowing of discriminatory intent. A government defendant can demonstrate that its decision or action would liave been the same without the presence of an illicit motive. ${ }^{65}$ The Court's provision for this defense is based on its recognition of the complex nature of official decisionmaking and the

59. 429 U.S. 252 (1977).

60. Id. at 267-68.

61. "Frequently the inost probative evidence of intent will be objective evidence of what actually happened rather than evidence describing the subjective state of mind of the actor. For normally the actor is presumed to have intended the natural consequences of his deeds." 426 U.S. at 253 (Stevens, J., concurring).

62. See, e.g., Arthur v. Nyquist, 573 F.2d 134, 142 (2d Cir.) ("when . . . actions have the 'natural, probable, and foreseeable result of increasing or perpetuating segregatiou,' a presumption of segregative purpose is created"), cert. denied, 439 U.S. 860 (1978); United States v. School Dist., 565 F.2d 127, 128 (8th Cir.), cert. denied, 434 U.S. 1064 (1977); NAACP v. Lansing Bd. of Educ., 559 F.2d 1042, 1046-48 (6th Cir.), cert. denied, 434 U.S. 997 (1977). See generally Note, The Role of Circumstantial Evidence in Proving Discriminatory Intent: Developments Since Washington v. Davis, 19 B.C.L. REv. 795 (1978); Note, Discriminatory Purpose and Discriminatory Impact: An Assessment After Feeney, 79 Colum. L. REv. 1376, 1391-96, 1407-13 (1979). Cf. Note, Reading the Mind of the School Board: Segregative Intent and the De Facto/De Jure Distinction, 86 YALE L.J. 317 (1976) (distinguishing between objective intent proven by reasonable foreseeability and "institutional intent" proven by foreseeable discriminatory consequences of official policies).

63. 442 U.S. 256 (1979).

64. Id. at 279 \& n.25. Accord, Columbus Bd. of Educ. v. Penick, 443 U.S. 449, 464-65 (1979); Dayton Bd. of Educ. v. Brinkman, 443 U.S. 526, 536 n.9 (1979). But see Coluunbus Bd. of Educ. v. Penick, 443 U.S. at 508-14 (Rehnquist, J., dissenting) (arguing that the Columbus Board of Education inajority held that foreseeability of disproportionate impact creates a presunption of discriminatory intent).

65. 429 U.S. at 270 u.21. See generally Schwemm, supra note 8, at 1019-23; Note, Discriminatory Purpose, supra note 62, at 1380-81; Comment, Proof of Racially Discriminatory Purpose Under 
difficulty of reviewing the balance of competing purposes and interests that influence every government decision. ${ }^{66}$ After Arlington Heights, the plaintiff's burden of proof is not only to provide evidence of the defendant's racially discriminatory intent, but also to show that any legitimate reason is only a pretext and that the official decision was contingent on an invalid purpose. ${ }^{67}$

\section{B. Consequences of Applying the Intent Test.}

Applying the intent-test holdings of Washington, Arlington Heights, and Feeney to Title VI litigation will have serious consequences for plaintiffs. Under the impact test, the minority plaintiff inust prove that his injury is a result of government action and that the injury is disproportionate to the harm suffered by the white cominunity. Under the intent test, to present a prima-facie case, the plaintiff must prove not only disproportionate impact, but also that the government acted with discriminatory intent. ${ }^{68}$

It is likely that the injured plaintiffs will not have participated in the decisionmaking process and will not have enjoyed equal access to

the Equal Protection Clause: Washington v. Davis, Arlington Heights, Mt. Healthy, and Williamsburgh, 12 HARv. C.R.-C.L. REv. 725, 745-52 (1977).

66. 429 U.S. at 265. See Washington v. Davis, 426 U.S. 229, 252-56 (1976) (Stevens, J., concurring). Justice Stevens emphasized that official decisionmaking is frequently the result of a balance of many different purposes rather than a single determinative cousideration.

67. The affirmative defense described by the Court remained as dicta, however, for the $\mathrm{Ar}$ lington Heights plaintiff failed to establish the necessary showing of racial discrimination. 429 U.S. at $270 \mathrm{n} .21$. Thns, although the Court nsed the opportunity to refine the operation of the intent test, fairly substantial questions remain unanswered. Those unresolved issues include: the appropriateness of evidentiary sources not listed in Arlington Heights; the differential weighting of evidence from varied sources; the standard of proof required from defendants; and the criteria to define acceptable governmental imterests. See, e.g., United States v. Texas Educ. Agency, 564 F.2d 162, 168 (5th Cir. 1977) ("ii]n neither Washington v. Davis nor Arlington Heights did the Supreme Court directly confront the issue of what type of official intent-subjective or objectivea plaintiff must show to present a prima facie case . . . .), cert. denied, 443 U.S. 915 (1979); Note, supra note 51, at 118. There is no rcason to believe that the Court has completed the process of articulating the elements of either the constitutional clallenge of discrimination or inore particularly the contours of the intent test.

In Mount Healthy City Bd. of Educ. v. Doyle, 429 U.S. 274 (1977), the Court remanded the case for a determination of whether the board of education could prove that it would have taken the same action toward the plaimtiff even in the absence of the plaintiff's constitutionally protected conduct. The shifting of the burden followed the plaintiff's showing that some of his conduct was protected under the first and fourteenth amendments and that the board's reaction to that conduct was a significant consideration in the board's decision not to rehire him. The Court directed the lower court to require from the board a "preponderance of the evidence" to establish its defense, but did not clarify any of the other questions regarding the intent test. Id. at 284-87.

68. See text accompanying notes 55-67 supra. 
all the information on which the government decision was based.69 Thus, it will be difficult for the plaintiffs to establish a prima facie case of their opponent's intent. ${ }^{70}$ As outsiders, minority-group plaintiffs will not be aware of all the historical antecedents to the government's decision or of the procedures by which the government evaluated alternatives and arrived at its final decision. ${ }^{71}$

When plaintiffs establish the inference of intent, the burden shifts to the defendants to rebut the inference. ${ }^{72}$ The defendants inay.demonstrate that their own decisions were inotivated by perimissible goals and purposes rather than by illegitimate racial considerations. As the Court recognized in Arlington Heights, defendants argue from their strongest position: their firsthand knowledge of the substance and weight given to various considerations involved in their official action. ${ }^{73}$

The result is a two-fold inquiry into intent: first, the plaintiff's prima facie case, and second, the defendant's affirmative defense. This arrangement is skewed because the plaintiff is required to provide evidence not only of his own injury, but also of the disproportionate impact of the government action, the presence of discriminatory intent, and the link between the government action and the illicit intent. The defendant, however, need only provide evidence of his own legitimate purpose. This arrangennent departs from the Washington Court's original balance between deference to governmental decisionmaking and the right to equal protection from conduct that discriminates on the

69. See, e.g., Castaneda v. Pickard, 648 F.2d 989, 1004 (5th Cir. 1981) (although MexicanAmericans are on the district school board they may not be in a position to exercise significant power over the district's employment decisions); Johnson v. City of Arcadia, 450 F. Supp. 1363, 1369-70 (M.D. Fla. 1978) (evidence of white-city officials' contmuing unresponsivcness to the needs of the black residents of Arcadia). See generally R. LINEBERRY, EQUALITY AND URBAN PoLICY (1977).

70. See Washington v. Davis, 426 U.S. 229, 253 (1976) (Stevens, J., concurring) ("It is unrealistic . . to require the victiun of alleged discrimination to uncover the actual subjective intent of the decisionmaker . . . "); Belton, supra note 8, at 1229, 1281-82; Kleven, The Supreme Court, Race, and the Class Struggle, 9 Hofstra L. Rev. 795, 806 (1981). Belton also questions the fairness of the allocation of burdens under the intent test. The fairness consideration suggests, im part, the fact that "evidence of a particular element may lie more within the knowledge or control of one party than another" and that the party in control of the knowledge should be asked to provide that information to the court. Belton, supra note 8, at 1218. See also Gomez v. Tolcdo, 446 U.S. $635,640-41$ (1980).

71. See text accompanying note 60 supra for a list of evidentiary sources from which plaintiffs can possibly garner proof of discriminatory intent. Real and testimonial evidence from these sources will most likely remain in the possession of the official decisionmakers.

72. See Washington v. Davis, 426 U.S. 229, 241 (1976).

73. See text accompanying notes 69-71 supra. See also Mount Healthy City Bd. of Educ. v. Doyle, 429 U.S. 274, 284-87 (1977). 
basis of race. ${ }^{74}$ The arrangement also chills the efforts of minority groups to challenge the official actions that they perceive as the reason for their discriminatory treatment. The Washington, Arlington Heights, and Feeney decisions create a difficult burden for the minority plaintiff who seeks relief from the injurious impact of government action. ${ }^{75}$

\section{Disproportionate IMPACT LEFT UNREMEDIED}

Placing the burden of proving imtentional discrimination on plaintiffs enhances the possibility that serious and injurious effects of government action that fall disproportionately on minority groups will go

74. See Washington v. Davis, 426 U.S. 229, 247-48 (1976). The Washington Court refused to extend the impact standard (applied in the Title VII case of Griggs v. Duke Power Co., 401 U.S. 424 (1971)) to the review of the constitutional claims. More deference to the "seemingly reasonable acts of [government] administrators and executives . . . is appropriate . . . where racial impact, without discriminatory purpose, is claimed." 426 U.S. at 247. Allowing a prima facie case to be established by claims that fail to demonstrate illicit purpose would create an overly intrusive rule that reaches too far to invalidate many government programs "designed to serve neutral ends" but which happen to be "more burdensome to the poor and the average black than to the more affuent white." Id. at 248. But see Belton, supra note 8, at 1281 (although judges are reluctant to intrude into the government decisionmaking process, they have also recognized that the process can mask discriminatory purpose).

75. Some scholars have noted that the Washington and Arlington Heights intent test are not in accord with the spirit of the equal protection guarantee. Professor Eisenberg described his discomfort as the result of an "intuitive feeling" that the courts should invalidate some government decisions solely because of the impact of those decisions. Eisenberg, Disproportionate Impact and Illicit Motive: Theories of Constitutional Adjudication, 52 N.Y.U.L. REv. 36, 42, 46, 47 (1977). Professor Brest writes:

If courts may grant relief only when plamtiffs have made a clear case on the record, many instances will remain where race-dependent decisions are strongly suspected but cannot be proved. Although this is not essentially different from the difficulty facing the proponents in most litigation seeking to overturn government policies, it is especially troubling in the race area. The accumulation of suspected but unproved race-dependent conduct, such as decisions to zone out low income housing, may systematically deprive minorities of important benefits. And the very existence of a state of affairs whicl "everyone knows" is based on racial discrimination but no one will reenedy is demoralizing and stigmatic.

Brest, Foreword: In Defense of the Antidiscrimination Principle, 90 HARV. L. REv. 1, 28-29 (1976).

Other authors have criticized the Court's fear of an unencumbered effects test, see, e.g., Washington v. Davis, 426 U.S. 229, 248 n.14 (1976), and have pointed for support to the reasonable results of the effects standard used in employment discrimination cases arising under Title VII of the Civil Rights Act of 1964, 42 U.S.C. $\$ \S 2000 \mathrm{e}-2000 \mathrm{e}-17$ (1976), and in voting rights cases arising under the Voting Rights Act of 1965, 42 U.S.C. $\$ \S 1971-1973$ (1976). See Fiss, Groups and the Equal Protection Clause, 5 Philosophy \& PUB. AFF. 107, 146 n.62 (1976); Schwemm, supra note 8, at 992-1000 ("the only justification advanced to support the Court's conclusion [in Washington $v$. Davis] was an unrealistic fear of a purely theoretical danger"). But see Perry, supra note 51, at 563-66 (discussing the impracticability of a pure disproportionate impact test and the need to balance the affected private interests with the underlying public interests). See also Freeinan, Legitimizing Racial Discrimination Through Antidiscrimination Law: A Critical Review of Supreme Court Doctrine, 62 U. MrN. L. REv. 1049, 1082-88 (1978); Kleven, supra note 70, at 797-807. 
unremedied under Title VI. ${ }^{76}$ One group of recent Title VI cases involves unsuccessful challenges to closings of public lospitals or reductions in their services.77 The impact of this type of government planning could be covered by the Title VI bar of discrimination in federally funded projects, but the use of the constitutional standard of intent has frustrated this statutory relief. The hospital closing cases serve as excellent examples of the types of disproportionate and injurious effects of government action that may remain unremedied under the intent interpretation of Title VI.

Congress did not anticipate the problems associated with hospital closings or relocations in its consideration of the policy goals that prompted the passage of Title VI in $1964 .{ }^{78}$ Significant changes, lowever, have taken place in the allocation of healtl care resources and the involvement of the federal government in health care since that time. ${ }^{79}$ These developinents, along with the existence and apparent permanence of the urban ghetto, ${ }^{80}$ have inade the public hospital an important institution for the cities' low income and minority communities. Without a public health-care facility, access to inedical services for residents of the urban ghetto is severely restricted. ${ }^{81}$ Officials' plans to close, reduce, or relocate inedical services accentuate public awareness of the crucial role of the hospital in the cominunity. Frequently conflict rages over the perceived and real injuries of the plan. ${ }^{82}$ In an in-

76. That is, the injurious effects of government action will go unremedied in the courts. See Belton, supra note 8, at 1224-25. No interpretation of Title VI precludes minority groups and their supporters from uniting to promote legislative change.

77. See, e.g., NAACP v. Medical Center, Inc., 657 F.2d 1322 (3d Cir. 1981); Bryan v. Koch, 627 F.2d 612 (2d Cir. 1980); Jackson v. Conway, 620 F.2d 680 (8th Cir. 1980); United States v. Bexar County, 484 F. Supp. 855 (W.D. Tex. 1980). See generally materials cited in note 4 supra.

78. See Wing, Title VI and Health Facilities: Forms Without Substance, 30 HASTINGS L.J. 137, 147-54 (1978); Note, NAACP v. Medical Center, Inc., supra note 4, at 586-88. See text accompanying notes 12-18, 34-39 supra.

79. The most significant expansion of the federal role in health care was the creation of Medicare, 42 U.S.C. \& 1395 (1976), and Medicaid, 42 U.S.C. \& 1396 (1976), finaneial assistance programs that reimburse inedical expenses of eligible elderly and indigent individuals. See gencrally Doing Better and Feeling Worse: Health in the United States (J. Knowles ed. 1977); Rosenblatt, Health Care Reform and Administrative Law: A Structural Approach, 88 YALE L.J. 243 (1978).

80. See gencrally RePORT Of THE NATIONAL ADVISORY COMmission ON CIVIL Disorders 236-73 (N.Y. Times ed. 1968).

81. Problems Facing Financially Troubled Hospitals: Ficld Hearings Before the Subcomm on Health of the House Comm. on Ways and Means, 96th Cong., 2d Sess. 191 (1980) (statement of Prof. Alan Sager) (hereinafter cited as Field Hearings); Deuschle, What is the Role of the Ghetro Hospital in Health Care Delivery?, in Medicine IN THE GHetTo 153 (J. Norman ed. 1969). See also A. Ford, URBAN HEALTH IN AMERICA (1976); Anodeo, The Closing and Divestiture of Public Hospitals: Public Responsibility for Health Care of Indigents, 9 Clearunghouse Rev. 174 (1975).

82. See, e.g., Sullivan, Rangel Sees Racist Parallels in Koch's Stand on Hospital, N.Y. Tines, May 22, 1980, § 2, at 3, col. 5 (discussing Bryan v. Koch, 627 F.2d 612 (2d Cir. 1980)). The district 
creasing number of these situations, relief is sought in federal ${ }^{83}$ or state $^{84}$ courts or through administrative channels. ${ }^{85}$

Even though no one-white or black-can use a hospital once it is closed, these closings threaten minority interests. Usually, the closed hospital disproportionately served blacks and hispanics ${ }^{86}$ and the new hospital is located in a predominantly white middle-class suburb. ${ }^{87}$ Taking away public services frustrates the eligible individual's entitleinent to Medicaid or Medicare ${ }^{88}$ and abandons individuals who are neither privately insured nor eligible for government aid to the unregulated decisions of private providers. ${ }^{89}$ Nationwide, there is evidence

court in Bryan found the plaintiff's challenge "frivolous" and an "effort . . . to use the federal courts as a last resort for delaying if not preventing" the city's decision. Bryan v. Koch, $492 \mathrm{~F}$. Supp. 212, 229, 217 (S.D.N.Y.), aff'd, 627 F.2d 612 (2d Cir. 1980). Cf. Pride v. Community School Bd., 488 F.2d 321, 328 (2d Cir. 1973) (the court recognized the anger and frustration experienced by the plaintiffs, but refused to recognize as an injury the feelings of inferiority the plaintiff's children would feel if the court held for the defendants).

83. Spivey v. Barry, 501 F. Supp. 1093 (D.D.C. 1980), rev'd, No. 80-2511, (D.C. Cir. Sept. 9, 1981); Jackson v. New York Health \& Hosp. Corp., 419 F. Supp. 809 (S.D.N.Y. 1976); See cases cited in note 77 supra.

84. See, eg., Concerned Citizens Comm. Interested in the Tehama Gen. Hosp. v. Board of Supervisors, 78 Cal. App. 3d 603, 144 Cal. Rptr. 300 (1978); Preston v. City of Philadelphia, 26 Pa. Commw. Ct. 106, 362 A.2d 452 (1976); 11 Clearinghouse Rev. 740 (1977) (summarizing Huron Community Health Comm. v. Fresno County Bd. of Supervisors, No. 217737-6 (Cal. Super. Ct., Sept. 2, 1977)); NAACP Fights Plan to Close Hospital, Hospitals, June 1, 1971, at 124 (regarding the proposed closing of Margaret Hague Maternity Hosp., Jersey City, New Jersey).

85. Federal administrative agency investigations were involved in NAACP v. Wilmington Medical Center, Inc., 491 F. Supp. 290 (D. Del. 1980), aff'd, 657 F.2d 1322 (3d Cir. 1981); Bryan v. Koch, 492 F. Supp. 212 (S.D.N.Y.), aff'd, 627 F.2d 612 (2d Cir. 1980); Jackson v. Conway, 476 F. Supp. 896 (E.D. Mo. 1979), aff'd, 620 F.2d 680 (8th Cir. 1980). A state administrative hearing was the forum for a challenge by the black residents of East Samt Louis to a closing of a private nonprofit hospital. See 13 CLEARINGHouse Rev. 114 (1979) (summarizing Sylvester v. Southwestern Ill. Health Facilities, No. 78-0178-H-082 (Ill. Health Facilities Planning Bd., filed 1979)).

86. See, e.g., Bryan v. Koch, 492 F. Supp. 212 (S.D.N.Y.), aff'd, 627 F.2d 612 (2d Cir. 1980); 13 Clearinghouse Rev., supra note 85, at 114. Cf. United States v. Bexar County, 484 F. Supp. 855 (W.D. Tex. 1980) (the services being closed in Bexar County were inaternity and gynecological care; the suit was brought on behalf of women who used the services).

87. See, e.g., NAACP v. Wilmington Medical Center, Inc., 491 F. Supp. 290 (D. Del. 1980), aff'd, 627 F.2d 1322 (3d Cir. 1981); United States v. Bexar County, 484 F. Supp. 855 (W.D. Tex. 1980); 13 Clearinghouse Rev., supra note 85, at 114.

88. See Note, NAACP v. Medical Center, Inc., supro note 4, at 590. See also 45 C.F.R. $\$ 80.3$ (b)(1)(iv) (1980) ("A recipient under any program [of federal assistance] . . may not . . . on ground of race, color, or national origin: . . . Restrict an individual in any way in the enjoyunent of any advantage or privilege enjoyed by others receiving any service .... under the program").

89. See, e.g., Bryan v. Koch, 627 F.2d 612, 626 n.8 (2d Cir. 1980) (Kearse, J., dissenting); Spivey v. Barry, 501 F. Supp. 1093, $1105-06$ (D.D.C. 1980), rev'd, No. 80-251I (D.C. Cir. Sept. 9, 1981); Supplemental Reply Brief for Appellant at 4-5, Bryan v. Koch, 627 F.2d 612 (2d Cir. 1980). See also Friedman, Public hospitals: Is "relevance" in the eye of the beholder?, Hospitals, May 1, 1980 , at 83. To illustrate the general reluctance of the private sector to deal with non-paying patients, Ms. Friedman quotes Jolın Sbarbaro, M.D., Assistant Commissioner of Health, City of Denver: 
that the percentage of minority population in an area is directly correlated with the probability of a hospital closing in or relocating out of that area. 90

\section{A. The Impact of a Hospital Closing.}

In contesting a hospital closing, plaintiffs typically present a detailed factual argument describing the nature and scope of the imjury to the minority community. A survey of the opinions in these cases indicates that courts have noted four kinds of impact associated with the closing of hospitals: (1) the violation of expectation interests based on the previous enjoyment of access to a hospital; (2) the disruption of the specific patterns of hospital use that match the ghetto residents' needs; (3) the unreliability of the private sector's commitment to health care for the city's mimority poor; and (4) the adverse effects on health care caused by increased inconvenience and travel time resulting from using an alternate public facility. ${ }^{91}$ Coinbining the particular facts in the hospital cases and a general social science understanding of the health care needs of the ghetto resident ${ }^{92}$ demonstrates the seriousness of the disproportionate impact suffered by the minority cominunity.

Hospital users form expectations that government will continue to provide the services they now enjoy. In some ways, the experience of having adequate and convenient hospital care and then losing it is more psychologically painful than the contmuous experience of being without adequate care.93 Moreover, taking away the hospital only

There are also many patients whom neither the private physician nor the private patient want to have contact with [thus leaving thein to public services]: the 'street person' who comes in drunk and perhaps violent; the 'mental lealth hold' whom the police bring in; the unique cultural or ethnic patient whose entire family may come with him and who needs interpretive services; the aged criminal, who is taken not to jail, but to the hospital; the criminal and the victim of crime, who are accompanied by the police; and the drug abuser. Private patients don't want to be near these social ills, and I don't blame them.

Id. at 92 .

90. Field Hearings, supra note 81, at 196.

91. For a discussion of these considerations, see text accoinpanying notes 93-126 infra.

92. See generally R. DUfF \& A. HollingShEAd, Sickness and SOCIETY (1968); K. KRAUSE, Power \& Illness: The Political Sociology of Health and Medical Care (1977); D. Mechanic, Medical Soctology (2d ed. 1978).

93. Cf. J. Thibaut \& H. Kelley, The Social Psychology of Groups (1959). Thibaut and Kelley, social psychologists, developed a concept of comparison level, $i d$. at 21-24, which they use to explain an individual's evaluation of the outcoines of a relationship. New outcomes are compared to salient past outcomes in the imdividual's experience. The coinparison level determines the subjective quahty or impact of the new outcome. "A person who has experienced superior outcomes, for example, in alternative relationships, will have a higher $C L$ [comparison level] and, therefore, will be less satisfied with the lower level in the present relationship than will another person who has known only the mediocrity of the present situation." Id. at 82.

This theoretical observation for individuals in dyadic relationships is easily extrapolated to explain the feelings of individual members of a group in imteraction with other groups. See $\mathbf{S}$. 
from the minority section of the city arguably creates a more psychologically harmful stigma than the historical denial of services to the minority section..$^{94}$

The courts have noted that both whites and minorities are deprived of a hospital's services when it closes and therefore have dis-

Stouffer, L. DeVinney, E. Suchman, S. Starr \& R. Williams, 1 Studies in Social PsyCHOLOGY IN WORLD WAR II, THE AMERICAN SOldIER (1949). Stouffer and his associates found that well-educated soldiers who had experienced better promotion outcomes and higher status prior to joining the army were less satisfied with the army's promotion schedule than less welleducated soldiers who were accustomed to fewer opportunities and less status. Id. at 284-361. By analogy, a community nember who has experienced convenient and adequate access to health care is injured more by denial of that access than the community nember who has never had such access. Cf. Cooper v. Aaron, 358 U.S. 1 (1958) (state's action to force a local school system to abandon already prepared plans is a violation of equal protection); Resident Advisory Bd. v. Rizzo, 425 F. Supp. 987 (E.D. Pa. 1976), (city acted with discriminatory intent in delaynig and frustrating the construction of a public housing project that had already begun (land was cleared in 1960)), aff'd, 564 F.2d 126 (3d Cir. 1977), cert. denied, 435 U.S. 908 (1978). But cf. Citizens Comm. for Faraday Wood v. Lindsay, 362 F. Supp. 651 (S.D.N.Y. 1973) (no discriminatory motive present in the refusal to process an application to obtain financing for the construction of public housing), aff'd, 507 F.2d 1065 (2d Cir. 1974), cert. denied, 421 U.S. 948 (1975). The Citizens Committee district court deferred to official decisionmakers, writing:

To hold that any action or failure to act is unconstitutional because it has an adverse effeet on mimorities, even though it affects inembers of the inajority as well-albeit to a lesser degree-would be carrying the idea of discriminatory effect too far. Under such an approach a governmental unit could never stop a program for entirely sound reasons even at an early talking stage if it would deprive minorities of something they would have lad if the program came to fruition.

362 F. Supp. at 659 . The observation of the district court cannot easily be explained away; nor does this note purport to provide a conclusive answer to this warning. The Supreme Court echoed the Citizens Committee court's concern in Washington v. Davis, 426 U.S. 229, 248 \& n.14 (1976), in which the Court expressed the fear that an impact test would invalidate reasonable and unintentionally discriminatory official actions. See note 75 supra. A hospital closing, however, is not the cancellation of a program yet to be started but rather the curtailment of a service upon which a community has come to rely.

94. Arguably, expectation interests are always being bruised by government action. Nonetheless, plaintiffs might argue that they have suffered separate damage to those expeetations based on the enjoyment of services prior to the hospital closing. Other plaintiffs who challenge an institutionalized, disproportionate distribution of health care services could argue that they suffered psychological injury by having less access to services but they could not claim injury from the loss of benefits which they had previously enjoyed. Cf. Jackson v. Conway, 476 F. Supp. 896, 904 (E.D. Mo. 1979) (distimguishing a hospital closing case from the inunicipal services cases in which services are provided to white areas but not to minority areas), aff $d, 620$ F.2d 680 ( 8 th Cir. 1980). In City of Menuphis v. Greene, 451 U.S. 100, 139-40 (1981) (Marshall, Brennan, Blackmun, J.J., dissenting), Justice Marshall recognizes the "psychological effect" on the minority comununity of the city's decision to erect a barrier prohibiting access along a street running from a white to a black neighborhood. The barrier does not represent a "slight inconvenience," id. at 138; rather, it " "serve[s] as a inonument to racial lostility" ", id. at 140 (quoting testimony). See generally The Supreme Court, 1976 Term, 91 HARv. L. REv. 70, 174-76 (1977) (suggesting an equal protection standard that would ask "whether a reasonable nember of the affected mimority group would be stigmitized by the challenged decisiou." Id. at 174). 
counted any special injury to minorities. ${ }^{95}$ One can question this supposition of nominal equality of loss, lowever, in light of the Suprene Court decision in Griffin v. County School Board.96 In Griffin the Court carefully reviewed an official decision to close an entire county public school systern, noting evidence of state action endorsing an alternative system of private schools in the county for whites only. .97 Although other evidence also supported the holding of unconstitutional discrimination, ${ }^{98}$ the Court independently recognized the violation of the minority plaintiffs' expectation interests resulting froin the closing of their school syste1n while public schools in surrounding counties reinained open. ${ }^{99}$ A loolding in favor of the official decisionmakers was not guaranteed even though the denial of services affected both blacks and whites in that county who attended public school. ${ }^{100}$

95. When part of a municipal hospital system is relocated, everyone must travel to the new location. E.g., NAACP v. Wilmington Medical Center, Inc., 491 F. Supp. 290, 320 (D. Del. 1980), aff'd, 657 F.2d 1322 (3d Cir. 1981); Umited States v. Bexar County, 484 F. Supp. 855,859 n.4 (W.D. Tex. 1980).

96. 377 U.S. 218 (1963).

97. Id. at $229-30$.

98. Id. at 222. The county's decision to close its schools was also in reaction to a court order to integrate the schools. Cf. Palmer v. Thompson, 403 U.S. 217 (1971) (City of Jackson, Mississippi, reacting to a federal court order to integrate public recreational facilities, closed all of its public swimming pools). The Palmer Court distinguished Griffin as also involving state action in support of alternative segregated private schools. Id. at 219, 221-23.

99. 377 U.S. at 230-31. See Horowitz \& Neitring, Equal Protection Aspects of Inequalities in Public Education and Public Assistance Programs From Place 10 Place Within a State, 15 U.C.L.A. L. REv. 787, 801-03 (1968). Horowitz and Neitring speculate that

more broadly viewed, [Griffin supports] . . . the principle that territorial inequalities of certain types within a state will be held violative of equal protection upon consideration of the magnitude of impact of the territorial classification on the individual adversely affected and the justification for the classification, and that local option-expressing local respouse to social, moral, economic, and political factors . . . is not, in itself, a controlling consideration which establishes adequate constitutional justification for the classification.

Id. at 803. The decision to close the most obsolete hospital in a community is arguably a territorial decision when the decision inevitably affects the downtown-ghetto hospital. Evidence of reasonable foreseeability of impact, however, is not by itself proof of discriminatory intent. See Persoimel Adm'r v. Feeney, 442 U.S. 256, 279 \& n.25 (1979).

The Griffin situation may also arise when a county decides to close all pubhic hospital services. See, e.g., Concerned Citizens Comm. Interested in the Tehama Gen. Hosp. v. Board of Supervisors, 78 Cal. App. 3d 603 (opinion omitted), 144 Cal. Rptr. 300, 304-05 (1978); HospiTALs, supra note 84 , at 124.

100. Cf. Umited States v. Palmer, 356 F.2d 951, 952 (5th Cir. 1966) (court dismissed the defendant's assertion that closing voter registration offices to both blacks and whites does not constitute discrimination "in a parish where most white persons of voting age are registered and most Negroes of voting age are not registered. . . . [T] $]$ here is no greater inequality than the cqual treatment of unequals." (quoting Dennis v. Umited States, 339 U.S. 162, 184 (1950)). Professor Eisenberg points out that "given the relative sociocconomic status of blacks and whites, one cannot help but feel that even though closing a public facility imjures whites, it usually does not hurt thcm as inuch as it hurts blacks." Eisenberg, supra note 75, at 109 n.344. But see Palmer v. Thompson, 
The second kind of impact evidence addresses the actual medical needs of inner city residents and the impact that closing a public lospital has on their access to inedical care. For example, in NAACP v. Wilmington Medical Center, Inc. ${ }^{101}$ the district court reviewed the needs of minority groups, the elderly, and the disabled ${ }^{102}$ - groups disproportionately represented in the patient population of the downtown Wilmington hospital. ${ }^{103}$ The inedical center proposed to move many specialty services, mcluding maternity services, to a new hospital in the Wilmington suburbs. The plaintiffs argued that the move disproportionately affected minorities because minority women and children have a greater incidence of high-risk pregnancies and births than white women and children. ${ }^{104}$ The court concluded that under the medical center's plan, services were to be inoved " 9.35 miles farther from the populations that need them most." 105 The plan called for an overall improvement in medical care for the cominunity but the plaintiffs argued that the relocation of services would actually decrease the com-

403 U.S. 217, 226 (1971) (holding that a local government's decision to close all of its municipal swimming pools, rather than allowing integrated use, did not violate the equal protection clause).

In NAACP v. Medical Center, Inc., 657 F.2d 1322, 1352 (3d Cir. 1981) (Gibbons, J,, concurring and dissenting), Judge Gibbons writes that he, unlike the majority, cannot find consolation in the district court's determination that the relocation of hospital services to the subnrbs and out of the inner city will improve the level of care for all population groups. The judge's doubts arise from the majority's reliance on the medical center's speculative promises to plan for significant renovation of the city facility. Id. at 1347, 1351-52. If the renovation is not carried out, all users will be disappointed, but the impact on the minority cominunity would be greater because the other branch of the hospital is much more accessible to the suburban white population. The ghetto hospital closing also imjures the expectations of minorities to a grcater extent than the expectations of whites because private sources of health care and even other public hospitals located outside of the ghetto remain open to provide services to the higher income and suburban white population.

101. 491 F. Supp. 290 (D. Del. 1980), affd, 657 F.2d 1322 (3d Cir. 1981).

102. Id. at 306-08. See also Greater Washington, D.C. Area Council of Senior Citizens v. District of Columbia Gov't, 406 F. Supp. 768 (D.D.C. 1975).

103. $491 \mathrm{~F}$. Supp. at 302-04.

104. Id. at 306-07. "[W]hile minorities comprise only $13 \%$ of the New Castle County population, they represent $33 \%$ of the patient days in pediatrics, $24 \%$ of the patient days in obstetrics, and $45.9 \%$ of the patient days in the premature nursery." Id. at 306. Socio-economic factors that help to explain this conclusion include: more pregnancies among minority teenage women; tendency of adolescents not to seek out prenatal care; and more pregnancies among older minority women and minority women in their fourth or more pregnancy. Id. at 306-07. See United States v. Bexar County, 484 F. Supp. 855, 859-60 (W.D. Tex. 1980) (Bexar County planned to relocate obstetrical and nursery facilities to the suburbs despite the disproportionate need for those services among residents of the inner city); A. ForD, supra note 81, at 66-67; HEALTH RESOURCES ADMINISTRAtion, Health of the Disadvantaged: ChaRT BooK-II 35-40 (1980).

105. 491 F. Supp. at 308. The Wilmington Medical Center court held that the various negative effects of the hospital service relocation were not sufficient to establish a prima facie case under an impact standard imterpretation of Title VI. Id. at 333-37. The court acknowledged the significance of the impact but reasoned that "the negative effects are only insignificant when compared to the vast improvements in the quality of care [under the medical center's plan]." Id. at 337. 
mumity's level of health: distance and imconvenience would discourage regular users and even high-risk users from seeking needed medical attention. 106

The emergency room of the urban public hospital also meets the particular needs of some inner-city users. In Bryan v. Koch ${ }^{107}$ the court recognized the emergency medical care needs of the community, observing that "at least a small number of patients, those admitted to the emergency room because of gunshot or knife wounds or drug overdoses, would suffer adverse consequences if the nearest emergency room treatment were at even shghtly more distant locations." 108 The public hospital emergency room also provides extensive services for non-emergency patients. ${ }^{109}$ The district court in Wilmington Medical Center correctly observed that the hospital clinic and emergency room are "used by the poor in much the same way as more affluent people use the services of a private pliysician." 110 Closmg a public hospital sharply reduces the availability of both emergency and primary health care for the ghetto commumity that relies on the lospital to meet the

106. Id. See text accompanying notes 144,147 infra regarding the presuinption of rational services users, and see text accompanying notes 122-26 infra regarding the effects of alternate transportation requirements.

107. 627 F.2d 612 (2d Cir. 1980). The New York City Health and Hospital Corporation made an administrative decision to close Metropolitan and Sydenham Hospitals in Harlem. Plaintiffs challenged the decision to close Sydenham through both political and judicial channels. The plaintiffs lost in the courts but negotiations resulted in the termination of municipal responsibility for the lospital and a plan to reopen the facility as a community-operated drug, alcohol, and mental health facility. N.Y. Times, July $13,1980, \S 1$, at 31 , col. 3 .

108. 627 F.2d at 617. Furtlermore, plaintiff' evidence sliowed that $70 \%$ of emergency room patients arrive by foot or are carried by others to the hospital; $85 \%$ of all drug overdose victims arrive in this manner. Brief for Plamtiffs at 12, 51, Bryan v. Koch, 627 F.2d 612 (2d Cir. 1980). In light of the closimg's adverse impact on these emergency patients, the Bryan court found it "appropriate" to assess the defendant's reasons for closing the hospital. 627 F.2d at 617. The court concluded that sufficient justification for closing on the basis of neutral criteria had been presented and held for the defendants. Id. at 620-21.

The medical deınands resulting from violence, alcoholisin, and drug addiction are disproportionately placed on the urban public hospital. See A. FoRD, supra note 81, at 58-67; D. MECHANIC, supra note 92, at 169-72; Rodstein, Crime and the Aged, 234 J.A.M.A. 533 (1975). Plaimtiffs in Bryan argued, in addition, that the public lospital needs extra beds for certain types of patients who cannot care for themselves, e.g., drug addicts and psychotic and senile patients. This use of lospital beds inay be inappropriate, but there is a chronic slortage of nore appropriate services in both the public and private sectors. Meinorandum in Support of Preliminary Injunction for Plaintiff at 16, Bryan v. Kocli, 492 F. Supp. 212 (S.D.N.Y.), affd, 627 F.2d 612 (2d Cir. 1980).

109. See generally Tetelman, Public Hospitals-Critical or Recovering?, 88 HEALTH SERVICES REP. 295, 298 (1973); Torrens \& Yedvab, Variations Among Emergency Room Populations: A Comparison of Four Hospitals in New York City, 8 MED. CARE 60 (1970).

110. 491 F. Supp. at 297; accord, Bryan v. Koch, 627 F.2d 612, 629 n.9 (2d Cir. 1980) (Kearse, J., dissenting). 
specific needs of its members. ${ }^{111}$

The third kind of impact associated with the closing of a public hospital is on the access of inembers of the affected groups to health care in the private sector. Private health providers may already be scarce in the low income community, ${ }^{112}$ and once the public facility is closed, private physicians may leave the area altogether. ${ }^{113}$ In the Wilmington Medical Center case, the plaintiffs contended that the opening of a new hospital would draw private physicians away from the neighborhood surrounding the old hospital and into the suburbs near the new facility. ${ }^{114}$ The doctors' relocation would reduce the availability of medical care in the city-both by a reduction of the staff of the old hospital ${ }^{115}$ and by a reduction in the number of physicians practicing in the community. ${ }^{116}$ The private sector's reaction to a hospital closing can affect access to health care in a community as much as the closing itself. ${ }^{117}$

The role of the private hospital in the community's health care system differs from that of the government-operated hospital. The private voluntary or for-profit hospital generally has a consumer orientation, providing services on the basis of profitability and extent of

111. In Jackson v. New York City Health and Hosp. Corp., 419 F. Supp. 809 (S.D.N.Y. 1976), the evidence showed that no more than $20 \%$ of the cases treated in the Morrisania Hospital emergency room were actual emergencies. The court reasoned that closing this public hospital would have less of an impact because so few patients presented true emergencies. The court ignored the probability, however, that the remaining patients who used the Morrisania emergency room would be without access to primary care if the city closed the hospital. Id. at 811-12. See also Wise, Medicine and Poverty, in Ethical Issues IN Medicine 347, 352-56, (F. Torrey ed. 1968) (discussing Morrisania Hospital and health care in the minority community).

I12. See, e.g., Bryan v. Koch, 627 F.2d 612, 626 n.9 (2d Cir. 1980) (Kearse, J. dissenting) ("the United States as a whole has slightly more than one doctor for every 500 people, Harlem has only one doctor for every 4000 people"). Also, access to minimally integrated facihties does not guarantee equal treatment for minorities. See R. DuFf \& A. HollingShEAD, supra note 92, at 107-50; A. Ford, supra note 81, at 97-98; S. HARRIs, The EConomics of HeAlth CARE $422-27$ (1975); K. KRAUSE, supra note 92, at 100-02; Haynes \& McGarvey, Physicians, Hospitals, and Patients in the Inner City, in Medicine IN THE GHeTto 117, 119 (J. Norman ed. 1969).

113. See Field Hearings, supra note 81 , at 199.

114. 491 F. Supp. at 309. But see id. at 329 (the court noted that private physicians will continue to locate their offices near their patients). See generally Memorandum in Support of Preliminary Injunction for Plaintiff at 12-13, Bryan v. Koch, 492 F. Supp. 212 (S.D.N.Y.), affd, 627 F.2d 612 (2d Cir. 1980); P. DeVise, Misused and Misplaced Hospitals and Doctors: A locational ANAlysis of the URBan Health CARE CRISIs 14 (1973); Field Hearings, supra note 81, at 199.

115. 491 F. Supp, at $309,329$.

116. Id. at 309.

117. In addition, some plaintiffs have contended that the lack of hospital facilities makes it more difficult to attract doctors to practice in a community or to work at outpatient clinics. Memorandum in Support of Preliminary Injunction for Plaintiff at 22, Bryan v. Koch, 492 F. Supp. 212 (S.D.N.Y.), aff d, 627 F.2d 612 (2d Cir. 1980). 
deinand by paying or insured patients. ${ }^{118}$ Although private hospitals inay benefit froin the closing of a public hospital coinpetitor, they escliew responsibility for the coinprehensive provision of care for all types of health-related probleins in the community. ${ }^{19}$ Furthermore, the residents liave no guarantee that the private hospital will reinain; a private provider nay decide to close or nove to the suburbs ${ }^{120}$ for inany of the same reasons that proinpt a city official's decision. ${ }^{121}$ The impact of closing a public hospital inust be assessed in light of the services offered by alternative private providers and the private hospital's commitment to inaintaining a presence in the community.

In every hospital closing case, plaintiffs inaintain that the remaining sources of medical care are inadequate substitutes for the public services being closed or relocated. Considerations relating to the fourth kind of impact surface in the debate over the ability of the remaining public services to ineet the health needs of the ininority community. In inost cases, the issue of alternatives turns on the effects of longer travel times and the accompanying inconveniences. Most courts have agreed with defendants that if public or private transportation is adequate to get patients to one hospital it will be adequate to get them to another. ${ }^{122}$ Differences in travel time are deemed to have only a minimal effect on the delivery of services. ${ }^{123}$ Plaintiffs successfully argued, however, in Spivey v. Barry, ${ }^{124}$ that increased travel time discourages the

118. One writer has suggested that those health-care providers who stay in the ghetto act like good businessmen. They offer certain routine services but have eliminated unprofitable facilities such as maternity wards and fully-equipped emergency roons. Slom, Hospital in Slum Turns a Profit by Providing Basic Care for the Poor, Wall St. J., Oct. 21, 1977, at 1, col. 1.

119. See Brown, The Public Hospital, Hospitals, July 1, 1970, at 40, 42; Friedman, supra note 89 , at 83-85.

120. E.g., NAACP v. Wilmington Medical Center, Inc., 491 F. Supp. 290, 294-99 (D. Del. 1980) (the medical center is a privately owned, non-profit corporation that receives federal funds under Medicare and Medicaid; the lawsuit was brought under Title VI to enjoin the medical center from curtailing its services in the inner city as a part of its plan to transfer its operation to the suburbs), aff'd, 657 F.2d 1322 (3d Cir. 1981); 13 CLEARINGhouse ReV., supra note 85, at 114.

121. See text accompanying notes $137-43$ infra.

122. See, e.g., United States v. Bexar County, 484 F. Supp. 855,859 n.4 (W.D. Tex. 1980) ("TT]he plaintiffs' claims of inaccessibility . . . are discounted by evidence that an overwhelming majority of all patients arriving at the ... [new hospital in the suburbs] did so by private automobile").

123. See Bryan v. Koch, 492 F. Supp. 212, 223 n.13 (S.D.N.Y.), affd, 627 F.2d 612 (2d Cir. 1980); Jackson v. Conway, 476 F. Supp. 896, 903-04 (E.D. Mo. 1979), affd, 620 F.2d 680 (8th Cir. 1980). See also NAACP v. Wilmington Medical Center, Inc., 491 F. Supp. 290, 305-06, $319-24$ (D. Del. 1980) (a plan to provide free shuttle bus transportation between facilities will mcet hospitalrelated transportation demand), affd, 657 F.2d 1322 (3d Cir. 1981).

124. 501 F. Supp. 1093, 1104-05 (D.D.C. 1980) (users of the Upshur Street Clinic in Washington, D.C. argued successfully that the District of Columbia's decision to close the clinic was a violation of their statutory rights under several District of Columbia statutes), rev'd, No. 80-2511 (D.C. Cir. Sept. 9, 1981). 
medically underserved from seeking services and that persons will wait until a health problem becomes serious and debilitating before traveling farther to a substitute clinic. ${ }^{125}$ The Spivey court agreed that the cost of care would increase and the chances for effective treatment would decrease because of the city's closing of the only health clinic in the minority neighborhood. ${ }^{126}$

\section{B. The Failure to Prove Intent.}

If a court determines the questions of fact on all four of these impact issues in the plaintiff's favor, the aggregate finding represents a substantial adverse and disproportionate impact on the minority coinmunity. Plaintiffs protesting hospital closings, however, have not yet presented persuasive evidence to meet the burden of proving racially discriminatory intent. In part, the plaintiffs' inability to show intent is the result of their non-participation in the decisionmaking process. Plaintiffs may attempt to show a departure from the normal official decisionmaking process, ${ }^{127}$ or the use of mistaken or inappropriate criteria, ${ }^{128}$ but the courts have accepted defendants' evidence of circumstantial exigencies to rebut the inference of intent based on the departure froin standard procedures. ${ }^{129}$ In defense, official decisionmakers have been able to show cooperation with cominunity groups, ${ }^{130}$ compromise on soine issues, ${ }^{131}$ and that average access to

125. Id. at 1099, 1105. The court remarked:

Without the availability of [geographically accessible] comprehensive clinical care, many indigent patients:

a. do not receive adequate preventive care, and therefore encounter complications and require more costly care later;

b. must utilize hospital emergency rooms for care, which is expensive; and

c. only receive care im a sporadic and fragmented manner, and do not receive care with the necessary continuity and coordination between various doctors, providers, and services.

Each of these problems has been posed by the closing of Upshur Street.

Id. at 1099. But see NAACP v. Wilmington Medical Center, Inc., 491 F. Supp. 290, 332 (D. Del. (1980) ("This Court . . . simply cannot believe that people will forego treatment for cancer, diagnosis or treatment for a neurological disorder, or care . . . merely because of a twenty-five minute imcrease im travel to and from the hospital in each direction"), affd, 657 F.2d 1322 (3d Cir. 1981).

See also A. Ford, supra note 81, at 96.

126. 501 F. Supp. at 1095-97.

127. See Village of Arlington Heights v. Metropolitan Hous. Dev. Corp., 429 U.S. 252, 267 (1977).

128. See Resident Advisory Bd. v. Rizzo, 564 F.2d 126, 143 (3d Cir. 1977), cert. denied, 435 U.S. 908 (1978).

129. E.g., NAACP v. Wilmington Medical Center, Inc., 491 F. Supp. 290, 313 n.181 (D. Del. 1980), affd, 657 F.2d 1322 (3d Cir. 1981).

130. E.g., Bryan v. Koch, 492 F. Supp. 212, 228-29 (S.D.N.Y.), affd, 627 F.2d 612 (2d Cir. 1980); NAACP v. Wilmington Medical Center, Inc., 491 F. Supp. 290, 299-302 (D. Del. 1980), affd, 657 F.2d 1322 (1981).

131. E.g., Bryan v. Koch, 492 F. Supp. 212, 227 (S.D.N.Y.), affd, 627 F.2d 612 (2d Cir. 1980). 
medical care will improve for the entire population over which they have jurisdiction. ${ }^{132}$ Attempts to prove discriminatory intent have failed ${ }^{133}$ because the decisionmaking process, which the public does not view, ${ }^{134}$ generates nost of the potential evidence of intent. ${ }^{135}$

Even if intent can be demonstrated, the courts have signaled their deference to the government's defense of legitimate objectives for its hospital-closing decisions. Such decisions are always justifiable and the justifications offered are generally true or substantially true. ${ }^{136}$ Reasons that decisionmakers give include: severe budget constraints forcing cities to cut public expenditures; ${ }^{137}$ the failure of payinents under Medicare and Medicaid to cover total hospital costs of those eligible for assistance; 138 the excessive cost of renovation and maintenance of old and deteriorating facilities in the central city-now the low-income sluins; ${ }^{139}$ the misinatch of overall user needs with the pres-

132. E.g., NAACP v. Wilmington Medical Center, Inc., 491 F. Supp. 290, 311 (D. Del. 1980), affd, 657 F.2d 1322 (3d Cir. 1981); United States v. Bexar County, 484 F. Supp. 855, 860 (W. D. Tex. 1980); Jackson v. Conway, 476 F. Supp. 896, 905 (E.D. Mo. 1979), affd, 620 F.2d 680 (8th Cir. 1980).

133. See Bryan v. Koch, 627 F.2d 612, 616 (2d Cir. 1980); NAACP v. Wilmington Medical Center, Inc., 491 F. Supp. 290, 313 \& n.181 (D. Del. 1980), aff'd, 657 F.2d 1322 (3d Cir. 1981); United States v. Bexar County, 484 F. Supp. 855, 859 (W. D. Tex. 1980).

134. Village of Arlington Heights v. Metropohtan Hous. Dev. Corp., 429 U.S. 252, 265 (1977); Washington v. Davis, 426 U.S. 229, 253 (1976) (Stevens, J., concurring). See generally Note, Reading the Mind of the School Board, supra note 62, at 332-37 (the author proposes a separate concept of "institutional intent" based on an identification and evaluation of institutional policies). See also J. March \& H. Simon, Organizations 136-71 (1958); Lindblom, The Science of "Muddling Through", 19 PuB. AD. Rev. 79 (1959).

135. But see NAACP v. Medical Center, Inc., 657 F.2d 1322, 1336 (3d Cir. 1981) (the requircnent that plaintiffs prove that feasible, less discriminatory alternatives to the medical center's plan exist is not unreasonable because of the extensive discovery available to the plaimtiffs).

136. Rehance on imaccurate statistics and misinformation has been raised, however, in hospital-closing litigation. See, e.g., Spivey v. Barry, 501 F. Supp. 1093, 1102-03 (D.D.C. 1980), rev'd, No. 80-2511 (D.C. Cir. Sept. 9, 1981); Letter from Coalition of Concerned Harlem Citizens and Organizations for Health to Patricia Harris, Secretary, Department of Health, Education, and Welfare 5 (August 20,1979) (arguing that health statistics on a block-by-block basis rather than on a health-district basis are more appropriate for making hospital closing decisions).

137. See, e.g., Bryan v. Koch, 627 F.2d 612, 614 (2d Cir. 1980); Spivey v. Barry, 501 F. Supp. 1093, 1103 (D.D.C. 1980), rev'd, No. 80-2511 (D.C. Cir. Sept. 9, 1981); United States v. Bexar County, 484 F. Supp. 855, 858 (W. D. Tex. 1980); Greatcr Washington, D.C. Area Council of Senior Citizens v. District of Columbia Gov't, 406 F. Supp. 768, 770 (D.D.C. 1975); Koch, Closing Sydenham, N.Y. Times, June 4, 1980, \$1, at 31, col. 1.

138. See, e.g., Trial Meino for Defendants at 31, Bryan v. Koch, 492 F. Supp. 212 (S.D.N.Y.), aff d, 627 F.2d 612 (2d Cir. 1980); Koch, supra note 137, at 31 .

139. See, e.g., Bryan v. Koch, 627 F.2d 612, 618 (2d Cir. 1980); Spivey v. Barry, 501 F. Supp. 1093, 1102 (D.D.C. 1980), rev'd, No. 80-2511 (D.C. Cir. Sept. 9, 1981); NAACP v. Wilmington Medical Center, Inc., 491 F. Supp. 290, 298, 301-02 (D. Del. 1980); affd, 657 F.2d 1322 (3d Cir. 1981); Trial Memorandum for Defendants at 24-30, Post Trial Memorandum for Defendants at 63-65, Bryan v. Koch, 492 F. Supp. 212 (S.D.N.Y.), aff d, 627 F.2d 612 (2d Cir. 1980). Plaintiffs commonly allege, however, that high costs of renovation result from intentionally planned obso- 
ent arrangement of services; ${ }^{140}$ low occupancy rates which generate unnecessary costs; ${ }^{141}$ and the decertification of specific hospital services. ${ }^{142}$ In addition, evidence that the entire system can operate more efficiently and less expensively if a facility is shut down, cut back, or relocated will usually serve as an affirmative defense. ${ }^{143}$

Deference to official justifications assumes that public-hospital systems must be guided by a cost-benefit model of priorities and that users act in a rational manner in seeking health-care services. ${ }^{144}$ In fact, the disagreement over the vahitity of these assumptions is at the heart of all of the complaints brought by affected minority groups.

Plaintiffs have raised three counter-arguinents. First, they claim that the public-sector hospital has a commitment to all of the cominu-

lescence. See Spivey v. Barry, 501 F. Supp. 1093, 1102 (D.D.C. 1980), rev'd, No. 80-2511 (D.C. Cir. Sept. 9, 1981); United States v. Bexar County, 484 F. Supp. 855, 857 (W. D. Tex. 1980). The possibility that past intentional discrimination is a consideration in an ostensibly neutral decision to elose a hospital supports a Title V1 or equal protection challenge. J. Stolier, A Health Advocate's Guide to Title VI of the 1964 Civil Rights Act and Section 504 of the Vocational Rehabilitation Act of 1973 at 18 (January 1979) (unpublished paper).

140. Defendants in Bryan argue that low income minority communities need outpatient facilities, not hospitals. Thus defendants claim that closing a hospital is not a curtailment of "needed" services. Post Trial Memoranduin for Defendants at 15, Bryan v. Koch, 492 F. Supp. 212 (S.D.N.Y.), affd, 627 F.2d 612 (2d Cir. 1980). They also contend that there is an excess of certain services, as evidenced by the underutilization of the surgical facilities at Sydenham Hospital. Trial Meinorandun for Defendants at 23, Bryan v. Koch, 492 F. Supp. 212 (S.D.N.Y.), affd, 627 F.2d 612 (2d Cir. 1980). Another contention is that the public hospital "inappropriately houses" the elderly who are chronically ill. Post Trial Mennoranduin for Defendants at 43 , Bryan v. Koch, 492 F. Supp. 212 (S.D.N.Y.), affd, 627 F.2d 612 (2d Cir. 1980). See generally Haggerty, What Type of Medical Care Can or Should be Offered to the Urban Poor?, in MEDicine IN THE GHETto 251 (J. Norman ed. 1969).

141. See, e.g., Jackson v. Conway, 476 F. Supp. 896, 905 (E.D. Mo. 1979), affd, 620 F.2d 680 (8th Cir. 1980); Trial Meinoranduin for Defendants at 20, Bryan v. Kocl, 492 F. Supp. 212 (S.D.N.Y.), affd, 627 F.2d 612 (2d Cir. 1980); Koch, supra note 137, at 31.

142. See, e.g., Reply Post Trial Memorandam for Defendants at 37, Bryan v. Kocl, 492 F. Supp. 212 (S.D.N.Y.), affd, 627 F.2d 612 (2d Cir. 1980) (decertification of Sydenham Hospital emergency department and relnoval of hospital from ambulance route indicates a decline in the hospital's quality of care).

143. See generally Gottheb, Reducing Excess Hospital Capacity is a Tough but Necessary Job, Hospitals, Dec. 1, 1978, at 63. Such official decisions, however, are difficult to review. See Bryan v. Koch, 492 F. Supp. 212, 220 (S.D.N.Y.), aff d, 627 F.2d 612 (2d Cir. 1980). Government planning is a complicated task. If the government decides as a matter of policy to close the most obsolete and financially wasteful facility, as soon as that facility is closed another facility will fit the same description. The problem of the systen "carrying" the most inefficient unit does not easily go away but, at the same time, a large system can always defend the closing of the presently most inefficient unit in order to benefit the whole.

144. See, e.g., Umited States v. Bexar County, 484 F. Supp. 855, 861 (W.D. Tex. 1980) ("Iprospective mothers] will have both the ability and good judgment to act in their best interest as well as that of their babies."). But see text accompanying notes I12-26 supra on the inadequacy of substitute providers. 
nity that takes precedence over cost-benefit strategies.145 Second, plaintiffs have marshalled evidence to demonstrate that closing a hospital is neither the only nor the best remedy to help solve fiscal problems. ${ }^{146}$ Finally, plaintiffs argue that users are not rational; individuals use a hospital for reasons other than to maximize the quahity of care received. Low-income users take advantage of medical services more often when the services are accessible and when the users know they will be treated regardless of their ability to pay. Because the reverse is often true in the ghetto, the poor generally make few visits to doctors for primary or preventive care. As a consequence, when their illnesses are treated, the illnesses are usually more severe than those of people in higher income groups and they require more and longer visits to the hospital. 147 Courts have been persuaded, however, by the official justification. In Medical Center and Bryan, the courts assumed for the sake of argument that the plaintiffs' evidence of impact established a prima facie case, yet in both cases the courts concluded that the official explanation was sufficient justification for the change in services, notwithstanding the resulting injury to minority access to health care. ${ }^{148}$

\section{CONCLUSION}

A gap exists between intentional discrimination covered by Title VI and the significant discriminatory impact resulting from official action or inaction. When a lospital closes, residents of the urban ghetto suffer disproportionately reduced access to necessary medical care. This problem is compounded by the absence of health-care alternatives available to groups previously served by the closed public hospitals. Even the most vigorous advocacy, however, will not establish a prima facie case under Title VI unless the plaintiffs can present evidence of

145. See Post Hearing Memorandum for Plaintiffs at 161, Bryan v. Koch, 492 F. Supp. 212 (S.D.N.Y.), aff d, 627 F.2d 612 (2d Cir. 1980); Friedman, supra note 89, at 83; Amodeo, supra note 81, at 174-75. Cf. Preston v. City of Philadelphia, $26 \mathrm{~Pa}$. Commw. Ct. 106, 362 A.2d 452 (1976) (plaintiffs' challenge depended almost entirely on the historical commitment of local government to public health care, implying that this traditional state function must be preserved). Also, a community inay develop pride in its local hospital and may for this reason resent the decision to close. Judge Clears Hospital Closing in St. Louis, Hospitals, Oct. 16, 1979, at 20.

146. E.g., Post Hearing Memorandum for Plaintiffs at 145-46, Bryan v. Koch, 492 F. Supp. 212 (S.D.N.Y.), aff d, 627 F.2d 612 (2d Cir. 1980) (incremental savings can be realized from sclcctive reductions of beds and consolidation of services). See generally Gottlieb, supra note 143, at 63.

147. See A. Ford, supra note 81, at 100-07. See also text accompanying notes 101-11 supra concerning the differential liealth needs of the urban low-income minority community.

148. NAACP v. Medical Center, Inc., 657 F.2d 1322, 1332-33 (3d Cir. 1981); Bryan v. Koch, 627 F.2d 612, 616-18 (2d Cir. 1980). 
discriminatory intent. Furthermore, this concern is not limited to the hospital-closing or -relocation situation; ${ }^{149}$ because of increased budgct reductions, federal courts inay soon hear a variety of benefits- and services- reduction cases. ${ }^{150}$ The expansion of government involveinent in the social service and health areas has created expectations and actual reliance, and the beneficiaries of those services will suffer greatly when that involvement is curtailed.

Congress enacted Title VI in 1964 to terminate the federal governinent's role as a provider of financial assistance to public and private progranns that operated in a discriminatory fashion. Congress intended Title VI to confront the problem at hand in 1964: intentional discrimination in state and local policies and programs. Since Title VI was enacted, however, the prevalence of official discriminatory purpose has receded. At present, adverse impact on minority communities inay result from facially neutral policies, and evidence of the requisite intent will be either elusive or altogether absent. Title VI, which once appeared to excise the federal government completely from actions and decisions that maintained racial segregation, is now inadequate to disentangle the imprimatur of contmued federal funding from other ac-

149. But see Jackson v. Conway, 476 F. Supp. 896, 904 (E.D. Mo. 1979) (distinguishing a hospital closing case from the municipal services cases in which services are provided to white areas but not to minority areas), affd, 620 F.2d 680 (8th Cir. 1980).

150. Chavkin, supra note 4 , at 566 , suggests that advocates who seek to improve or preserve access to health care continue to rely on civil rights statutes like Title VI. The wave of rednctions in government health and social welfare assistance expenditures have already generated court action. See, e.g., Philadelphia Citizens in Action v. Schweiker, No. $81-4452$ (E.D. Pa. Nov. 20, 1981), rev'd, Nos. 81-2915, 81-2916, 81-2942 (3d Cir. Jan. 15, 1982) (unsuccessful challenge of the Department of Health and Human Services' reduction in welfare assistance under the Administrative Procedures Act, 5 U.S.C. $\$ 553$ (1976)); Coleman v. O'Bannon, No. $81-5003$ (E.D. Pa. Feb. 11, 1982) (state law prohibits a reduction in the eligibility standard for welfare benefits); Wolinsky \& Possley, Hospitals File Suit to Stop State Medical Cutbacks, Chicago Sun-Times, Aug. 7, 1981, at 4 , col. 1 (suit filed in federal district court to stop State's plan to reduce Medicaid payinents to hospitals). Other cutbacks lrave met with serious opposition which may turn into challenges of the government actions in court. See, e.g., Rich \& Teeley, HUD Aides Warn Cuts Could Mean Riots at Projects, Wash. Post, Dec. 4, 1981, at Al, col. 3 (reactions to proposed cuts in federal housing programs); Russell, OMB Memo Proposes Closing St. Elizabeths, Wash. Post, Dec. 3, 1981, at A1, col. 4 (Office of Management and Budget proposal to close federal facility for the mentally ill in the District of Columbia); Engel, Public Health Service Hospilals Going Under, Wash. Post, Oct. 7, 1981, at A25, col. 3 (reactions to Department of Health and Human Services decision to close public health service hospital system consisting of eight liospitals and 27 chincs around the country); Robinson, City May Sue U.S. Over CETA Cuts, Wash. Post, Mar. 28, 1981, at C1, col. 4 (District of Columbia government reacts to cuts in Comprehensive Training and Employinent Act funding which affects over 1,000 jobs in District of Colunbia area). $C$. Rich, HHS Trims List of 'Medically Underserved Areas', Wash. Post, Nov. 4, I981, at A23, col. 2 (redefining "inedically underserved area" will inean elimination of federal health care assistance from previously assisted urban ghetto areas). So far, none of the reports of these most recent challenges lias inentioned express reliance on Title VI to support the claims of those who oppose the reductions in government benefits and services. 
tions and decisions that have severe racially disproportionate effects. To redistribute health care services away from the residents of the urban ghetto not only creates the stigma of unequal treatment warned agamst in Brown v. Board of Education, ${ }^{151}$ but it also places those residents dangerously at risk because of inadequate access to medical care.

Mitchell A. Horwich

151. 347 U.S. 483, 493-96 (1954). See generally R. KLUGER, SIMPLE JUSTICE: THE HistoRY OF Brown v. Board of Education AND BLACK AMERICA's STRUGGLE FOR EQUALITY 315-45 (1975); Appendix to Brief for Appellant, Brown v. Board of Education, 347 U.S. 483 (1954), reprinted in 37 MiNN. L. REV. 427 (1953). 